\title{
Sulfate Ion Removal from Water Using Activated Carbon Powder Prepared by Ziziphus Spina-Christi Lotus Leaf
}

\author{
Morteza Rahmati, ${ }^{1}$ Golan Yeganeh ${ }^{2}$ and Hossein Esmaeili ${ }^{3, *}$ \\ ${ }^{1}$ Department of Chemical Engineering, Datshtestan Branch, Islamic Azad University, Dashtestan, Iran \\ ${ }^{2}$ Young Researchers and Elite Club, Bushehr Branch, Islamic Azad University, Bushehr, Iran \\ ${ }^{3}$ Department of Chemical Engineering, Bushehr Branch, Islamic Azad University, Bushehr, Iran \\ *Corresponding author: E-mail: esmaeili.hossein@gmail.com \\ \&esmaeili.hossein@iaubushehr.ac.ir
}

Received: 02-28-2019

\begin{abstract}
In this paper, the adsorption potential of activated carbon prepared by Ziziphus spina-christi lotus leaf for the removal of sulfate from aqueous solution was investigated. To this end, the effect of different parameters such as $\mathrm{pH}$, contact time, temperature, adsorbent concentration, and initial sulfate ion concentration was investigated. The results indicated that the highest adsorption efficiency $(84.5 \%)$ was obtained at $\mathrm{pH} 6$, adsorbent concentration of $5 \mathrm{~g} / \mathrm{L}$, sulfate ion concentration of $20 \mathrm{ppm}, 65 \mathrm{~min}$ and temperature of $45^{\circ} \mathrm{C}$. Also, the adsorption equilibrium study showed that the adsorption process follows the Langmuir isotherm model with the maximum adsorption capacity of $9.3 \mathrm{mg} / \mathrm{g}$. In addition, the thermodynamic study showed that the adsorption process on the activated carbon surface was spontaneous. Moreover, the adsorption process was exothermic accompanied by a decrease in irregularity. Furthermore, the adsorption kinetic study indicated that the adsorption process follows the pseudo-second-order kinetic model.
\end{abstract}

Keywords: Adsorption; lotus leaf; sulfate ion; water purification

\section{Introduction}

Industrial and urban effluents are one of the main pollutants which can cause environmental pollution. ${ }^{1}$ Among the pollutants, sulfate is one of the significant inorganic pollutants found in urban effluents and with different amounts in industrial wastewaters; its concentration in lakes and seas is increasing quickly due to the urban and industrial effluents drainage. ${ }^{2}$

When too much sulfate gets into the human stomach, it endangers health. Sulfate along other minerals cause pipe corrosion. Also, it may cause undesirable taste in water, diarrhea in human and young livestock. The taste threshold varies between $250 \mathrm{mg} / \mathrm{L}$ sodium sulfate and $1000 \mathrm{mg} / \mathrm{L}$ calcium sulfate. The undesirable taste of water usually gets reduced at values below $250 \mathrm{mg} / \mathrm{L}$. Also, the maximum desirable amount of sulfate in drinking water is $250 \mathrm{mg} / \mathrm{L}$ and its maximum permitted is $400 \mathrm{mg} / \mathrm{L}$. $^{3}$

Several methods such as distillation, reverse osmosis, ion exchange, and adsorption are available for sulfate removal from water. ${ }^{4}$ Physicochemical treatment systems such as ion exchange, reverse osmosis and electrodialysis are costly and produce sludge, which is difficult to dispose. ${ }^{5} \mathrm{Ad}-$ sorbents are widely used among many technologies for the removal of anions from water. Also, the adsorption method is economically feasible, frequent, diverse, effective, simple and eco-friendly. ${ }^{6-9}$ In recent years, many researchers have been attracted to cheap adsorbents. ${ }^{8-15}$ The use of activated carbon has been introduced as a widely used method for sulfate removal due to its efficiency and easy usage. ${ }^{6}$

Any carbon material can be used to produce activated carbon. Up to now, several studies have been conducted using activated carbon derived from agricultural wastes such as peanut crust, nuts shell, tamarind shell, peanut shell, ${ }^{16}$ rice bran, rice hulls, banana peel, orange peel, apple peel, hazelnut, walnut shell, tree's leaf and bark, oak essence, cane bagasse, corn, wheat bran, sawdust, sunflower stem, grape stem, modified algae, alfalfa and mustard ${ }^{13-15,17-27}$ for the removal of pollutants from wastewater.

In this work, the activated carbon powder obtained from lotus leaf was used to remove sulfate ion from aqueous solution and the effect of different parameters such as temperature, contact time, $\mathrm{pH}$, adsorbent concentration 
and sulfate ion concentration in aqueous solution were investigated and also, the optimum operational conditions for getting maximum adsorption was obtained. Lotus or Cedar is a plant from jujube family which grows wildly in Saudi Arabia, North Africa and Southern Iran which is used in this work. ${ }^{28}$ Therefore, this plant is economically preferred a lot. Also, the adsorbent surface properties were studied via different analyses such as SEM, EDAX, FTIR, BET, and XRD. Eventually, the kinetic, equilibrium and thermodynamic studies of adsorption process were carried out and the adsorption process characteristics were investigated.

\section{Materials and Method}

\section{1. Chemical}

In this work, sodium sulfate decahydrate with a purity of $99 \%$ was purchased from Merck Co., Germany. The $\mathrm{HCl}$ and $\mathrm{NaOH}$ made by Merck Co. (Germany) were also used to adjust the $\mathrm{pH}$ of the samples.

\section{2. Stock Solution}

In order to prepare a stock solution containing sulfate ion, a certain amount of sodium sulfate decahydrate was poured into a $250 \mathrm{ml}$ Erlenmeyer and double-distilled water was added to it to reach a volume of $100 \mathrm{ml}$. Standard solutions with low sulfate concentrations were prepared through diluting a certain volume of this stock solution using double-distilled water.

\section{3. Preparation of Lotus Leaf Powder}

In order to prepare activated carbon adsorbent from lotus leaf, first, the leaves were washed with a lot of distilled water to remove dust. Then, they were placed in an oven at $100{ }^{\circ} \mathrm{C}$ for 60 minutes to completely dry. The dried leaves were placed in a furnace under $700{ }^{\circ} \mathrm{C}$ for 2 hours until they turned to charcoal. After carbonization, the leaves turned to powder by milling and graded through sieve No. 25 then stored inside anti-moisture plastic bottles.

\section{4. Adsorbent Analysis}

BET, SEM, FT-IR, EDAX, and XRD analyses were used to determine structural and morphological properties of activated carbon produced from Lotus leaves. In order to determine the functional groups in the adsorbent, the FT-IR Perkin device was used; surface structure and adsorption morphology was determined by SEM (Philips-x130), the XRD device made by GNR Npd3000 company was used to determine the adsorbent crystalline phases, the EDAX device (Philips-x130) was used to determine the adsorbent elements and the adsorbent specific surface area was determined through BET device (Philips model, USA).

\section{5. Adsorption Experiments}

Adsorption experiments were conducted in a batch manner. To do this, the effect of sulfate ion concentration $(20,40,60,80,100$ and $120 \mathrm{mg} / \mathrm{L})$, contact time (5 to 80 minutes), adsorbent dose (1-10 g/L), $\mathrm{pH}$ (4 to 10) and temperature $\left(25,35,45,55,65\right.$ and $\left.75{ }^{\circ} \mathrm{C}\right)$ on the sulfate ion adsorption from aqueous solution was investigated. In all experiments, the mixing speed was considered 200 $\mathrm{rpm}$. The residual sulfate ion in the solution was obtained by spectrophotometer (DR 5000 Hach, USA). To this end, $10 \mathrm{~mL}$ sample volume containing sulfate ion was added to the device to measure the remaining sulfate at a wavelength of $450 \mathrm{~nm}$.

First, in order to get the optimum $\mathrm{pH}, 7$ samples of $100 \mathrm{ml}$ aqueous solution containing $100 \mathrm{ppm}$ sulfate ion were prepared. Then, the $\mathrm{pH}$ of the solutions was adjusted by $\mathrm{NaOH}(\mathrm{IM})$ and $\mathrm{HCl}(1 \mathrm{M})$ at the $\mathrm{pH}$ values from 4 to 10 . After that, $5 \mathrm{~g} / \mathrm{L}$ of activated carbon adsorbent was added to each sample containing sulfate ions and stirred by a magnetic stirrer with a mixing rate of $200 \mathrm{rpm}$ at room temperature for $60 \mathrm{~min}$. Then, the solution was filtered by Whatman filter paper, the adsorbent was removed and the amount of residual sulfate ion was obtained within the solution. The sulfate adsorption percentage by the adsorbent (\%A) is calculated for each sample using equation (1), so the best $\mathrm{pH}$ value for maximum removal efficiency was achieved.

$$
\% A==\left(\frac{C i-C o}{C i}\right) \times 100
$$

where $C_{\mathrm{i}}$ and $C_{\mathrm{o}}(\mathrm{mg} / \mathrm{L})$ are the initial concentration and the equilibrium concentration of the metal ion.

In order to investigate the adsorbent concentration effect in aqueous solutions, the effect of different concentrations of 1 to $10 \mathrm{~g} / \mathrm{L}$ were considered. After that, $5 \mathrm{~g} / \mathrm{L}$ of adsorbent was added to each aqueous solution with different concentrations at optimum $\mathrm{pH}$; the solutions were stirred by magnetic stirrer with a mixing rate of $200 \mathrm{rpm}$ at $25^{\circ} \mathrm{C}$ for $60 \mathrm{~min}$. After a specific time, the process was stopped and the solution was filtered by Whatman filter paper (No. 42) and the adsorbent was separated from the solution. Then, the residual sulfate ion in the solution was obtained and the best adsorbent concentration that is most adsorbed was determined. In order to determine the effect of other parameters, the same actions were performed. At each stage, in order to examine each parameter, other parameters considered as constant and the optimum values in the previous stage were used.

\section{Results and Discussion}

\section{1. Characteristics of the Adsorbent}

BET analysis determines the specific surface area of the adsorbent (cavities identification and surface roughness). Working with this device is based on measuring the amount of neutral gas adsorption, such as nitrogen, at a 

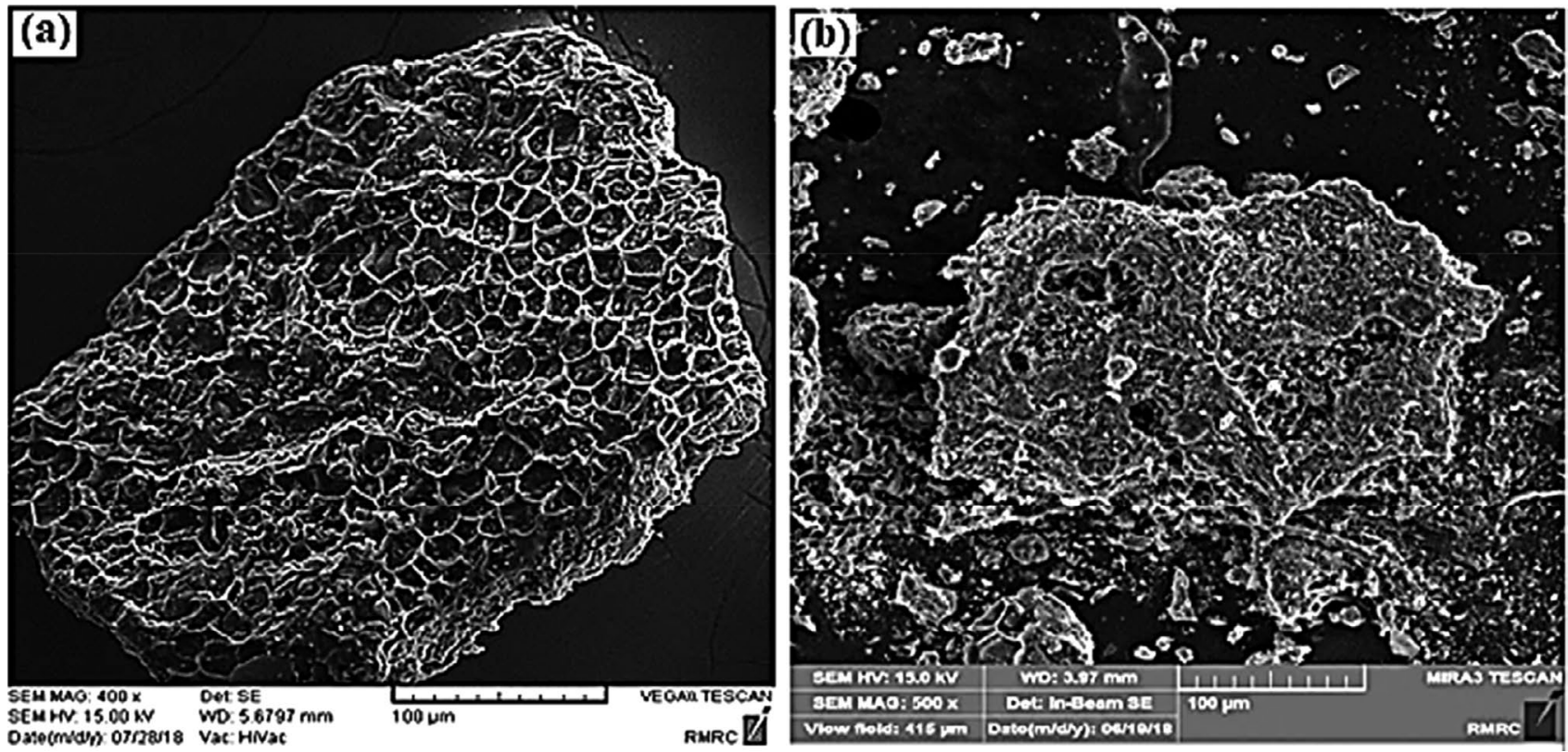

Figure 1. SEM analysis of adsorbent before (a) and after adsorption (b)

constant temperature on the adsorbent surface. The results showed that the adsorbent surface area of the lotus leaf is $51.024 \mathrm{~m}^{2} / \mathrm{g}$. Also, the average pore diameter (ADP) and the total pore volume (TPV) of Lotus leaf adsorbent are obtained $196.573 \mathrm{~A}$ and $0286800 \mathrm{~cm}^{3} / \mathrm{g}$.

SEM device was used to identify the adsorbent structure and morphology before and after the sulfate ion adsorption process. SEM images of the Lotus leaf adsorbent before and after adsorption are shown in Fig.1. As known, there are many roughness and cavities on the adsorbent surface which leads to adsorbent surface area increase representing different sites for sulfate ion adsorption. These cavities are coated after sulfate ion adsorption process which is clearly shown in the figure.

Fig. 2 shows the XRD pattern of the lotus leaf adsorbent. The spectra in 229 and $40^{\circ}$ are related to Calci-

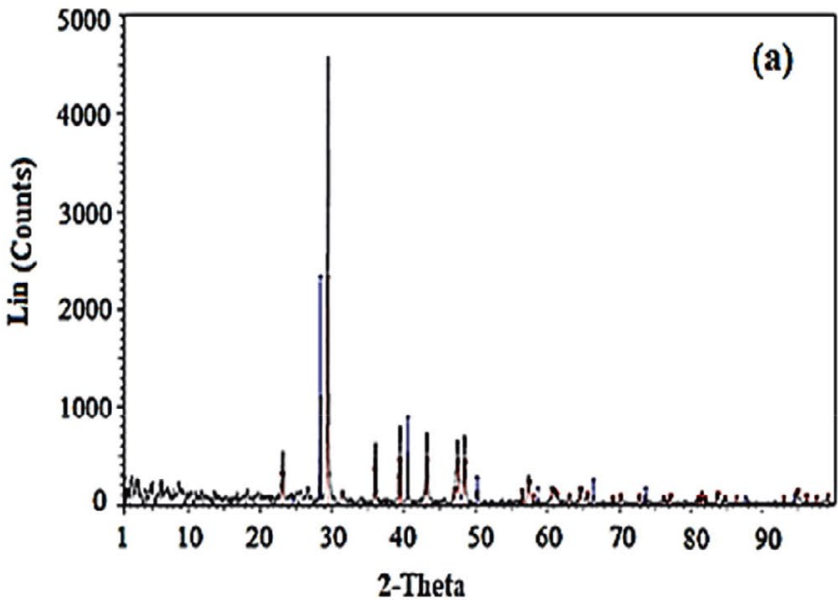

um Carbonate and the spectra in $2 \theta 28$ and $34^{\circ}$ are related to Potassium Chloride. According to Debye-Scherrer equation, the average diameters of Lotus leaf adsorbent crystals were determined $25.12 \mathrm{~nm}$. Also, the spectra in $2 \theta 0.499$ and 0.998 are related to empty cavities in the adsorbent.

Also, in the XRD analysis after adsorption, spectra in $2 \theta 29$ and $40^{\circ}$ are related to Calcium Carbonate and the spectra in $2 \theta 28$ and $34^{\circ}$ are related to Potassium Chloride. According to Debye-Scherrer equation, the average diameters of Lotus leaf adsorbent were determined $29.88 \mathrm{~nm}$. Also, the spectra in $2 \theta 0.499$ and 0.998 are related to empty cavities in the adsorbent sample. By comparing the graphs before and after adsorption, it can be seen that both graphs have very similar peaks which shows that the adsorbent structure has not changed much after adsorption.

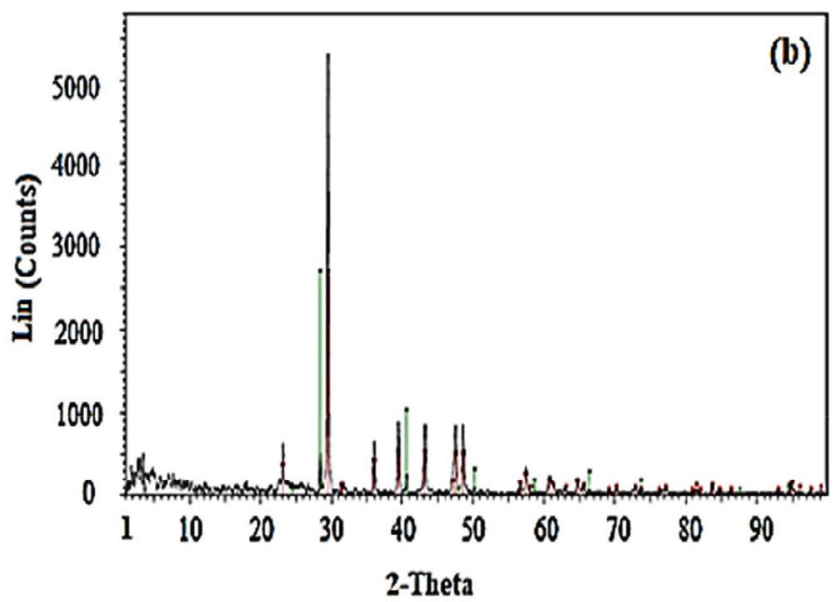

Figure 2. XRD analysis of activated carbon adsorbent before (a) and after adsorption (b) 


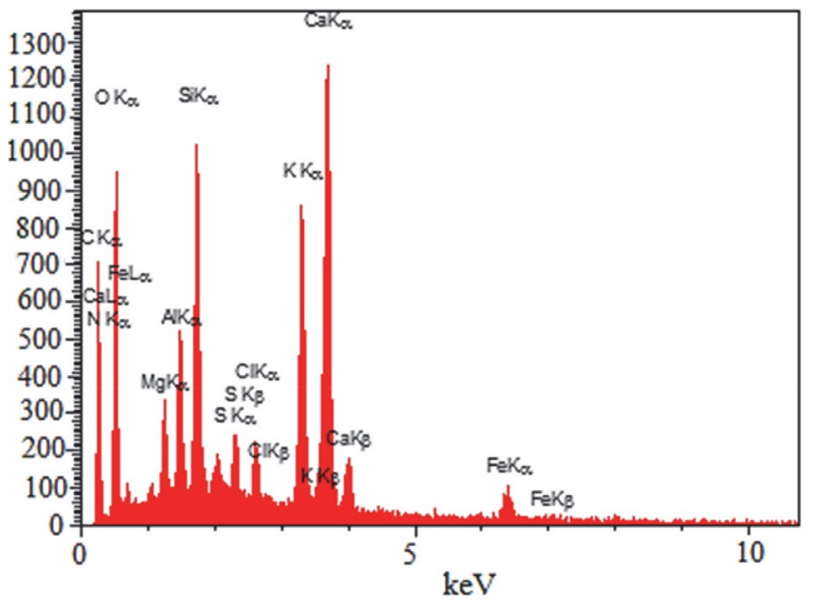

Figure 3. EDAX analysis of activated carbon adsorbent

Also, the EDAX analysis on the Lotus leaves for the adsorbent elements determination is shown in Fig. 3 and Table 1 . As is evident in the Fig, there are various elements such as Fe, Ca, K, Cl, S, Si, Al, Mg, O, C, N in the Lotus leaf sample which their weight percentage are $2.39,11.96$, $6.81,1.15,1.22 \%, 4.40,2.11,1.39,38.89,25.80$ and $3.86 \%$, respectively. So, the most important components in its structure were oxygen and carbon.

Table 1. Elemental analysis of the adsorbent by EDX apparatus

\begin{tabular}{lcc}
\hline Elements & Weight (\%) & Atomic (\%) \\
\hline $\mathrm{C}$ & 25.80 & 37.47 \\
$\mathrm{~N}$ & 3.86 & 4.81 \\
$\mathrm{O}$ & 38.89 & 42.40 \\
$\mathrm{Mg}$ & 1.39 & 1.00 \\
$\mathrm{Al}$ & 2.11 & 1.37 \\
$\mathrm{Si}$ & 4.40 & 2.73 \\
$\mathrm{~S}$ & 1.22 & 0.66 \\
$\mathrm{Cl}$ & 1.15 & 0.57 \\
$\mathrm{~K}$ & 6.81 & 3.04 \\
$\mathrm{Ca}$ & 11.96 & 5.20 \\
$\mathrm{Fe}$ & 2.39 & 0.75 \\
Total & 100.00 & 100.00 \\
\hline
\end{tabular}

Also, the FTIR analysis results for functional groups determination in the $400-4000 \mathrm{~cm}^{-1}$ range are shown in Fig. 4 . The results show that the spectrum of $798.795 \mathrm{~cm}^{-1}$ is related to the aromatic tensile bond of $-\mathrm{C}-\mathrm{H}, 1016.45 \mathrm{~cm}^{-1}$ frequency shows the $\mathrm{C}-\mathrm{O}$ group (carboxylic acid), $1315.19 \mathrm{~cm}^{-1}$ frequency shows the $\mathrm{C}-\mathrm{F}$ functional group, $2158.81 \mathrm{~cm}^{-1}$ frequency shows the functional group of $\mathrm{C} \equiv \mathrm{C}, 3101.21 \mathrm{~cm}^{-1}$ frequency shows the $\mathrm{H}-\mathrm{O}$ (alcohol) functional group and the frequency of $3451.37 \mathrm{~cm}^{-1}$ shows the $\mathrm{N}-\mathrm{H}$ functional group (amide).

\section{2. The pH Effect on Adsorption}

The initial $\mathrm{pH}$ of the solution containing sulfate ions affects the changes in surface charge of the adsorbent and

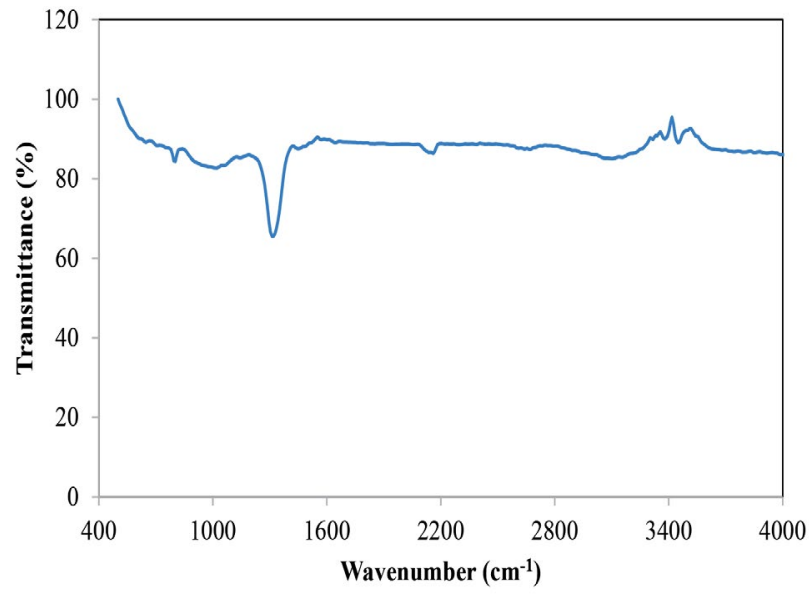

Figure 4. FT-IR analysis of activated carbon adsorbent

the adsorption mechanism of sulfate ions in the adsorption process. ${ }^{29}$ Also, the initial $\mathrm{pH}$ of the solution is considered as one of the important parameters during the adsorption process. ${ }^{30}$ Because the existing hydrogen ions $\left(\mathrm{H}^{+}\right)$in the aqueous solution compete with other ions to sit on the adsorbent surface. Also, the initial $\mathrm{pH}$ of the solution affects the variations of adsorbent surface charge and ionization degree of the adsorbed material (sulfate) during the adsorption process. The $\mathrm{pH}$ effect on the $\mathrm{SO}_{4}^{2-}$ ion adsorption on the activated carbon surface derived from lotus leaf is shown in Fig. 5.

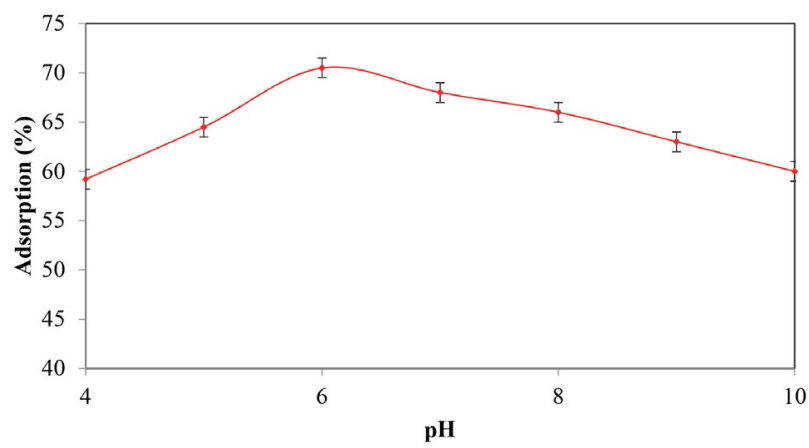

Figure 5. The $\mathrm{pH}$ effect on the $\mathrm{SO}_{4}^{2-}$ ion adsorption using the activated carbon derived from lotus leaf (Other conditions: $\mathrm{T}=298 \mathrm{~K}$, $\left.\mathrm{m}=0.5 \mathrm{~g}, \mathrm{Tc}=60 \mathrm{~min}, \mathrm{SO}_{4}=100 \mathrm{mg} / \mathrm{l}\right)$

As shown in the figure, the sulfate ion adsorption efficiency increases by raising $\mathrm{pH}$ from 4 to 6 . Since the ambient is acidic at low $\mathrm{pH}$, so, the Hydrogen ions concentration in the aqueous solution is high and since the hydrogen ion is placed on the adsorbent surface, the adsorbent load gets positive; therefore, the electrostatic force makes adsorption between the adsorbent positive load and Sulfate anion negative load. The maximum percentage of sulfate ion adsorption happens at $\mathrm{pH}=6$. Sulfate anion is better adsorbed at low pHs. After that, sulfate adsorption decreases. The maximum adsorption of sulfate ion 


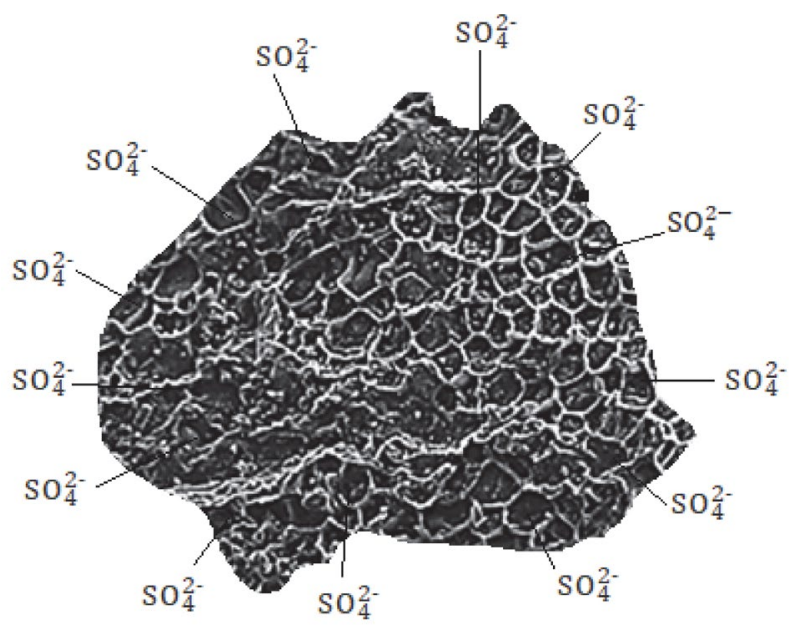

Figure 6. The adsorption mechanism of sulfate ions on the active sites of the activated carbon

through Lotus leaf was obtained $70.5 \%$. The adsorption efficiency decreased after $\mathrm{pH}=6$ and by changing the $\mathrm{pH}$ from 6 to 10, sulfate ion adsorption percentage decreased from 70.5 to $60 \%$. At this point, the hydroxide ion concentration increases inside the solution which leads to $\mathrm{SO}_{4}\left(\mathrm{OH}^{-}\right)$hydrolysis, complex formation and sulfate ion sedimentation is as $\mathrm{SO}_{4}\left(\mathrm{OH}_{2}\right)$ Due to the sediment and complex formation, sulfate ions decreased in the aqueous solution, subsequently reduced the adsorption efficiency. Fig. 6 shows the adsorption mechanism of sulfate ions for sitting on the active sites of the adsorbent.

\section{3. The Effect of Adsorbent Dose}

Adsorption dose is one of the important parameters on the adsorption process because it represents the maximum adsorption rate. ${ }^{31}$ The effect of adsorption dose on the sulfate ion adsorption efficiency is shown in Fig. 7. According to the graph, increasing the adsorbent concentration from 1 to $5 \mathrm{~g} / \mathrm{L}$ caused significant changes in adsorption. By increasing the adsorbent dose from 1 to 5 $\mathrm{g} / \mathrm{L}$, sulfate ion adsorption percentage increases from 45 to

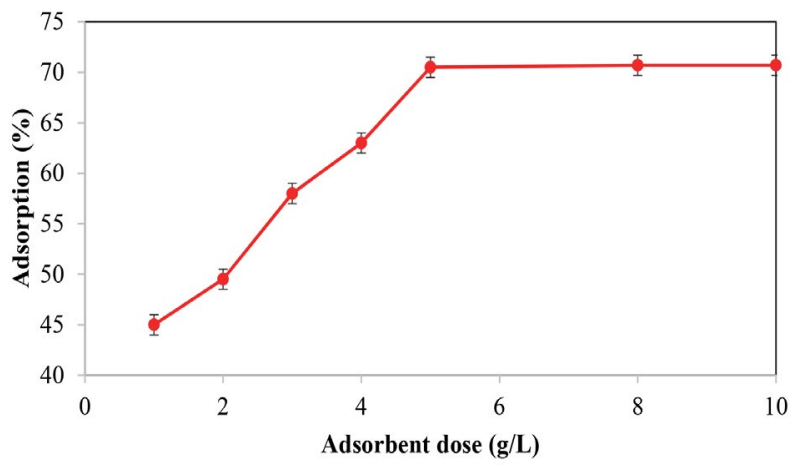

Figure 7. The effect of the adsorbent dose on the adsorption of sulfate ion $\left(\mathrm{T}=298 \mathrm{~K}, \mathrm{pH}=6, \mathrm{Tc}=60 \mathrm{~min}, \mathrm{SO}_{4}=100 \mathrm{mg} / \mathrm{L}\right)$
$70.5 \%$. Also, at concentration more than $5 \mathrm{~g} / \mathrm{L}$, no change in adsorption was observed. The increase in slope at the beginning of the graph is mainly due to the increase of adsorbent surface area and a large number of active sites for sulfate ion adsorption.

\section{4. The Contact Time Effect on the Adsorption Amount}

The effect of contact time on the adsorption of sulfate ion from aqueous media using activated carbon prepared by lotus leaf is shown in Fig. 8.

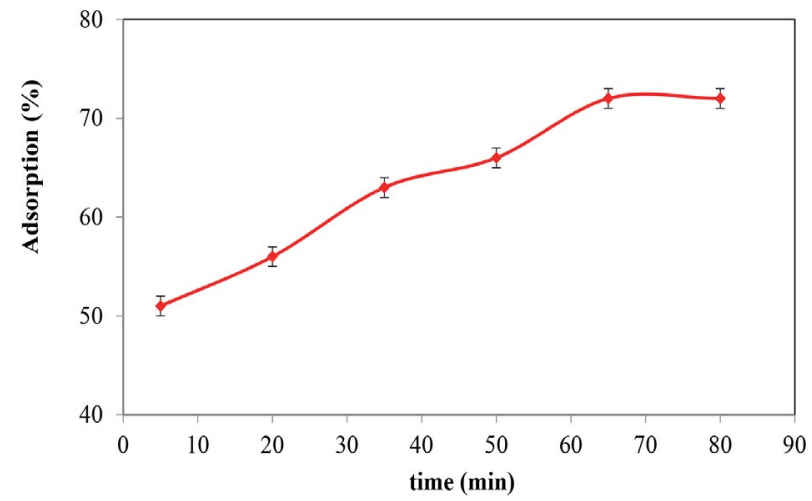

Figure 8. The effect of contact time on the adsorption of sulfate ion $(\mathrm{T}=298 \mathrm{~K}, \mathrm{~m}=0.5 \mathrm{~g}, \mathrm{pH}=6$, sulfate ion concentration $=100 \mathrm{mg} / \mathrm{L})$

According to the figure, the optimum time for $\mathrm{SO}_{4}^{2-}$ ion adsorption on the active carbon surface is $65 \mathrm{~min}$ utes. For sulfate ion adsorption as shown in the graph, the graph's slope gets sharper by increasing the contact time, the slope steepness means that adsorption has occurred at high rate, because many active sites on the adsorbent surface are empty at the beginning of the sulfate ion adsorption process through Lotus leaf adsorbent and sulfate is placed on the sites. Therefore, the removal percentage has been increased by increasing the contact time; the graph's slope remained constant after 65 minutes and sulfate removal percentage got balanced. After $65 \mathrm{~min}$, the sulfate removal efficiency remained constant due to the saturation of adsorbent active sites. Therefore, the contact time of 65 min was considered as the optimum time for sulfate ion adsorption.

\section{5. Temperature Effect}

Another important parameter in the adsorption process is temperature. This parameter indicates that the adsorption process is exothermic or endothermic. The temperature effect on $\mathrm{SO}_{4}^{2-}$ ion adsorption on the active carbon surface is shown in Figure 9.

According to the figure, when temperature increases from 298 to $348 \mathrm{~K}$, the sulfate removal percentage by the 


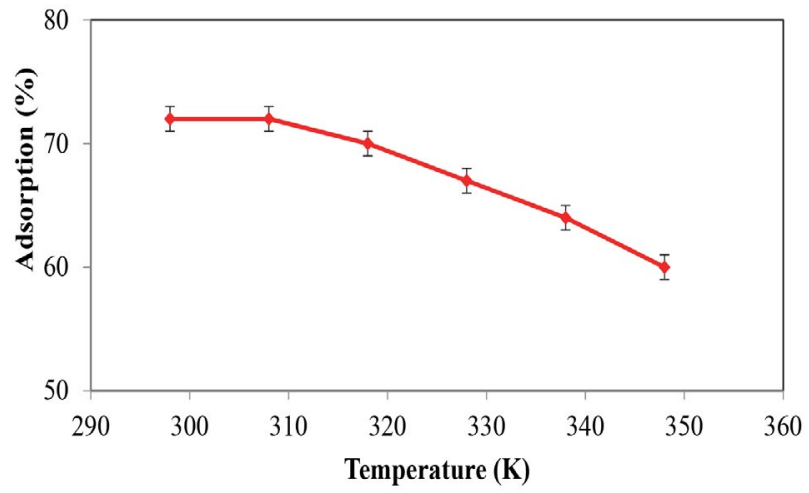

Figure 9. Temperature effect over $\mathrm{SO}_{4}^{2-}$ ion adsorption on the activated carbon derived from lotus leaf (Other terms: $\mathrm{Tc}=65 \mathrm{~min}, \mathrm{~m}$ $=0.5 \mathrm{~g}, \mathrm{pH}=6, \mathrm{SO}_{4}=100 \mathrm{mg} / \mathrm{L}$ )

adsorbent decreases. This percentage decrease is due to the molecular movement reduction. The adsorption reaction rate decreases by the molecular movement reduction. On the other hand, according to le Chatelier principle, adsorption level decreases when the temperature rises. This is somehow associated with irregularities reduction. The adsorption capacity reduction by temperature increase represents an exothermic reaction. Therefore, the optimum adsorption temperature for $\mathrm{SO}_{4}^{2-}$ ion is $298 \mathrm{~K}$.

\section{6. The Initial Concentration of $\mathrm{SO}_{4}^{2-}$ Ion}

In the adsorption process, the initial concentration of metal ions in aqueous solution plays an important role as the mass transfer force between the solution and solid phase (adsorbent). The sulfate ion concentration effect on the removal from aqueous solution is shown in Fig. 10. At initial concentrations, the ratio of active sites to the initial concentration of sulfate in aqueous solution raises, so, the

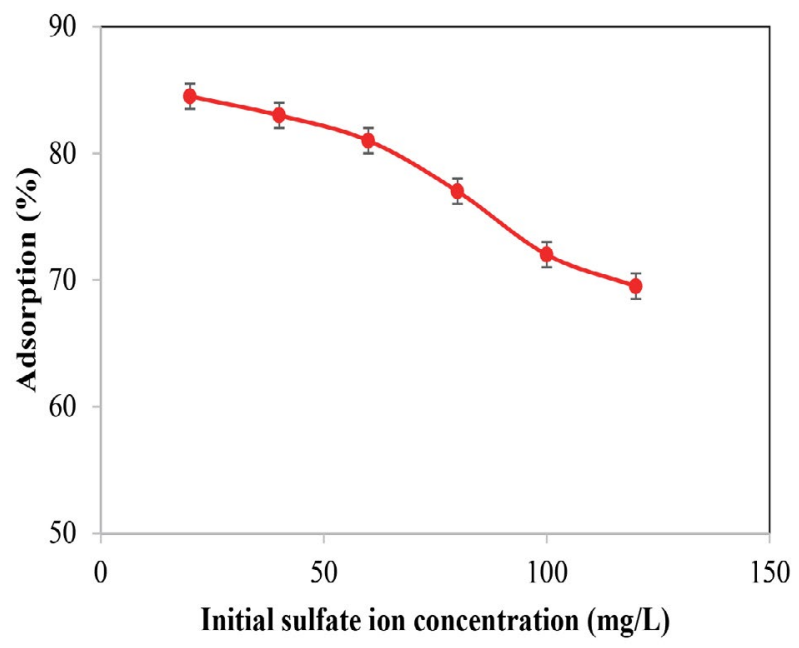

Figure 10. The investigation of $\mathrm{SO}_{4}^{2-}$ ion's initial concentration on the adsorption over the carbon surface derived from Lotus leaf (Other conditions: $\mathrm{T}=298 \mathrm{~K}, \mathrm{~m}=0.5 \mathrm{~g}, \mathrm{pH}=6, \mathrm{Tc}=65 \mathrm{~min}$ ) interaction between adsorbent and sulfate ion increases and anion gets removed from aqueous solution. The adsorption efficiency of sulfate ion decreased by increasing the initial sulfate ion concentration which is ascribed to the competition of sulfate ion to sit on active sites of the adsorbent. Also, the ions in the aqueous solution can be able to be interacted with prepared adsorbent and be removed from the aqueous solution. ${ }^{17}$ Therefore, the initial ion concentration of $20 \mathrm{mg} / \mathrm{L}$ with an adsorption efficiency of 84.5 was considered as an optimum value.

\section{7. Adsorption Isotherm Study}

The adsorption isotherm study presents information about the effective interaction between adsorbent and the absorbed. In order to evaluate the equilibrium adsorption, the Langmuir, Freundlich, Temkin and Dubinin-Radushkevich isotherm models were studied. The Langmuir adsorption isotherm is used for monolayer adsorption on surfaces with limited identical adsorption positions. The linear form of this model is described as follows: ${ }^{29,32}$

$$
\frac{1}{q_{e}}=\frac{1}{K_{L} q_{m}}\left(\frac{1}{C_{e}}\right)+\frac{1}{q_{m}}
$$

For determining the $K_{L}$ and $q_{\mathrm{m}}$, the slope and intercept of $1 / q_{\mathrm{e}}$ based on $1 / C_{\mathrm{e}}$ can be used. One of the based uses of Langmuir's constant is to determine the separation factor $\left(R_{L}\right)$ according to Equation (3). If $R_{L}>1, R_{L}=0$ or $0<R_{L}<1$, the process will be undesirable, irreversible, linear and desirable, respectively. ${ }^{33}$

$$
R_{L}=\frac{1}{1+K_{L} C_{i}}
$$

Also, the Freundlich isotherm describes the adsorption on inhomogeneous surfaces with uniform energy sites. The linear form of Freundlich isotherm follows from Equation $4 .{ }^{33}$

$$
\log q_{e}=\log K_{f}+\frac{1}{n} \log C_{e}
$$

In this equation, if $1 / \mathrm{n}$ is between zero and one, it shows that the adsorption process intensity is non-uniform at all levels. If $1 / n$ is less than one, it shows that the adsorption process has been chemical and when $1 / n$ value is more than 1 , the adsorption process will be physical.

In these equations, $q_{e}$ is the amount of adsorbed pollutant $(\mathrm{mg} / \mathrm{g})$ at the equilibrium time, $q_{m}$ is the maximum adsorption capacity by adsorbent $(\mathrm{mg} / \mathrm{g}), C_{\mathrm{e}}$ is the equilibrium concentration of absorbed component $(\mathrm{mg} / \mathrm{L})$ and $K_{L}$ is the equilibrium constant $(\mathrm{L} / \mathrm{mg})$ which depends on the degree of absorbed component tendency towards adsorbent; $K_{F}$ and $\mathrm{n}$ are Freundlich isotherm constants which represent the capacity and intensity of adsorption, respectively.

In the Langmuir model, $K_{L}$ and $q_{m}$ are obtained from the slope and intercept of $1 / q_{\mathrm{e}}$ based on $1 / C_{\mathrm{e}}$. Also, in the 
Freundlich model, $K_{F}$ and $\mathrm{n}$ are calculated from the slope and intercept of $\log q_{e}$ versus $\log C_{e}$.

Temkin model is another isothermal model. In this double-parameter model, it is assumed that the adsorption is monolayer and heterogeneous. The linear form of this model is as follows:

$$
q_{e}=B_{T} \operatorname{Ln} A_{T}+B_{T} \operatorname{Ln} C_{e}
$$

$\mathrm{A}_{\mathrm{T}}$ is the Temkin constant based on $\left(\mathrm{L} \mathrm{mg}^{-1}\right)$ and it is compatible with adsorbent-absorbed adhesion.

The $\mathrm{B}_{\mathrm{T}}$ constant is defined as ${ }^{B_{r}}=\frac{R T}{K_{T}} . K_{T}$ is the Temkin constant based on $\left(\mathrm{J} \mathrm{mol}^{-1}\right)$ which is proportionate with adsorption heat. The $\mathrm{A}_{\mathrm{T}}$ and $\mathrm{B}_{\mathrm{T}}$ amounts are calculated from the slope and intercept of $q_{e}$ based on $\ln C_{e}$.

The Dubinin-Radushkevich (D-R) isotherm model which is a semi-experimental relation. It assumes that the adsorption process is monolayer, so, it can be both chemical and physical. This model assumes that the surface is uneven, it has a linear form as follows:

$$
L n q_{e}=L n q_{d}-K_{D} \varepsilon^{2}
$$

Here, $q_{\mathrm{d}}$ is the $\mathrm{D}$ - $\mathrm{R}$ isotherm constant which is proportionate with saturation capacity expressed by $\mathrm{mg} \mathrm{g}^{-1}$. $K_{D}$ is another constant based on $\left(\mathrm{mol} \mathrm{J}^{-1}\right)^{2}$ expressed by $E=-0.7 K_{D}^{-0.5}$. More negative free energy means the adsorption is more chemical. Finally, $\varepsilon$ represents the Polanyi potential $(\mathrm{J} / \mathrm{mol})$ defined by the $\varepsilon=R T I n\left(1+\frac{1}{C_{c}}\right)$ equation. This is calculated by drawing $\operatorname{Ln} q_{e}$ graph based on
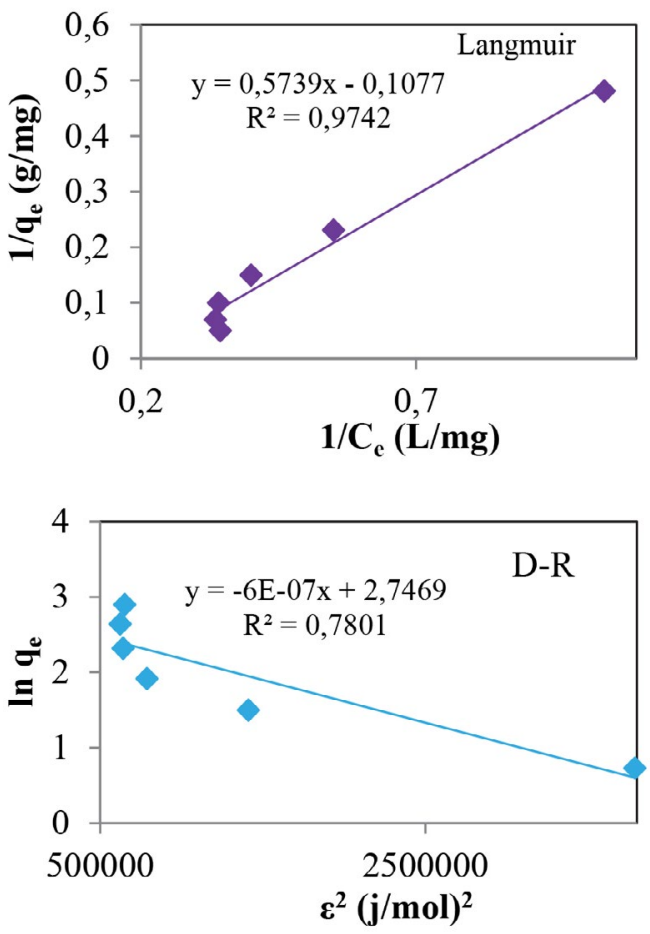

$\varepsilon^{2}$, and $q_{d}$ and $K_{D}$ are measured by its slope and intercept. $^{34}$

The isothermal results are shown in Tables 2 and 3 and Figure 11. According to these results, the correlation coefficient $\left(\mathrm{R}^{2}\right)$ in Langmuir isotherm model is higher than other models and also closer to 1; showing that Langmuir isotherm model has more capability for describing the isothermal behavior of adsorption process which also indicates the monolayer adsorption nature of sulfate ion

Table 2. The results of various isotherms of $\mathrm{SO}_{4}^{2-}$ ion adsorption on the activated carbon surface derived from Lotus leaf (Other terms: $\mathrm{T}=298 \mathrm{~K}, \mathrm{~m}=0.5 \mathrm{~g}, \mathrm{pH}=6, \mathrm{Tc}=65 \mathrm{~min}$ )

\begin{tabular}{llr}
\hline Isotherm & Parameter & value \\
\hline Langmuir & $q_{\mathrm{m}}(\mathrm{mg} / \mathrm{g})$ & 9.3 \\
& $K_{\mathrm{L}}(\mathrm{L} / \mathrm{mg})$ & 0.2 \\
& $\mathrm{R}^{2}$ & 0.9742 \\
& $n$ & 0.61 \\
\hline Freundlich & $K_{\mathrm{F}}(\mathrm{mg})^{1-\mathrm{n}} \mathrm{L}^{\mathrm{n}} \mathrm{g}^{-1}$ & 2.0 \\
& $\mathrm{R}^{2}$ & 0.8719 \\
& $\left.A_{\mathrm{T}}(\mathrm{L} \mathrm{mg})^{-1}\right)$ & 1.1 \\
\hline Temkin & $B_{\mathrm{T}}$ & 10.576 \\
& $\mathrm{R}^{2}$ & 0.6071 \\
& $q_{\mathrm{d}}(\mathrm{mg} / \mathrm{g})$ & 15.6 \\
\hline $\mathrm{D}-\mathrm{R}$ & $K_{D} \times 10^{-6}(\mathrm{~mol} / \mathrm{J})^{2}$ & 6.0 \\
& $E(\mathrm{~kJ} / \mathrm{mol})$ & -903.7 \\
& $\mathrm{R}^{2}$ & 0.7801 \\
\hline
\end{tabular}
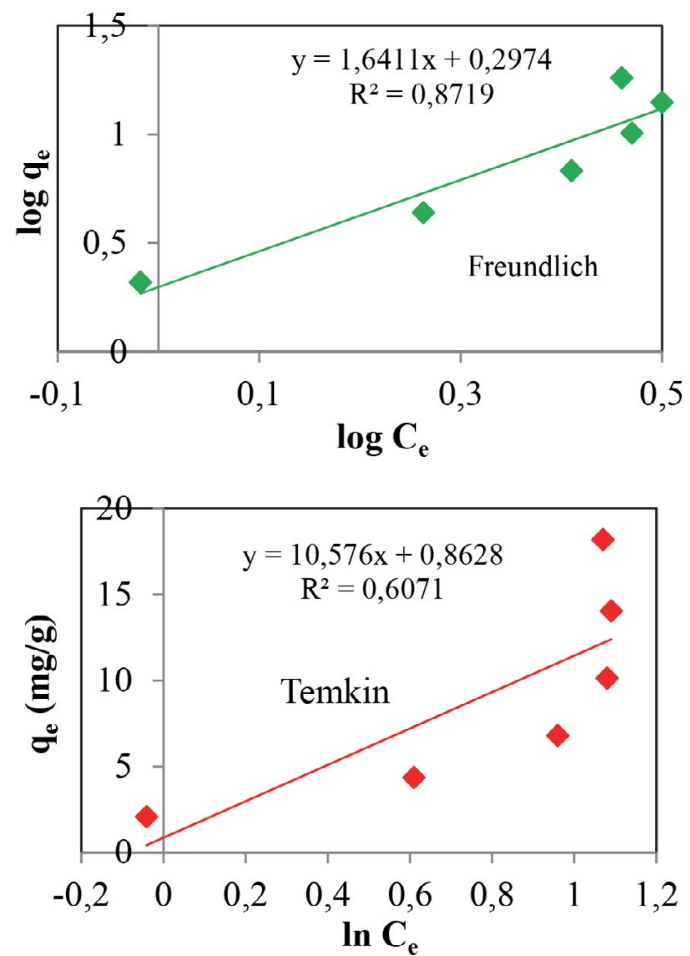

Figure 11. Adsorption isotherms of $\mathrm{SO}_{4}^{2-}$ ion on the activated carbon surface including Langmuir, Freundlich, Temkin, and Dubinin-Radushkevich isotherms

Rahmati et al.: Sulfate Ion Removal from Water Using Activated ... 
Table 3. The amount of adsorption separation factor of various $\mathrm{SO}_{4}^{2-}$ ion concentrations on the activated carbon surface derived from Lotus leaf, regarding the $\mathrm{R}_{\mathrm{L}}$

\begin{tabular}{lcccccc}
\hline Initial ion concentration (mg/L) & 20 & 40 & 60 & 80 & 100 & 120 \\
$\mathbf{R}_{\mathbf{L}}$ & 0.71 & 0.6 & 0.5 & 0.4 & 0.33 & 0.3 \\
\hline
\end{tabular}

on the adsorbent's heterogeneous surface. Also, Temkin and $\mathrm{D}-\mathrm{R}$ isotherm models are not suitable due to their data dispersion and low correlation coefficient. Furthermore, in the Freundlich model, the $\mathrm{n}$ value was determined 0.61 for sulfate ion adsorption which indicates that sulfate ion adsorption mechanism through Lotus leaf adsorbent is physical. The $R_{L}$ values at sulfate ion concentrations between 20 and $120 \mathrm{mg} / \mathrm{L}$ were obtained between 0 and 1 . The $\mathrm{R}_{\mathrm{L}}$ values show that the adsorption process is desirable and reversible.

\section{8. Thermodynamic Study}

Thermodynamic parameters include enthalpy changes $\left(\Delta H_{a d s}\right)$, entropy $\left(\Delta S_{a d s}\right)$ and Gibbs free energy $\left(\Delta G_{a d s}\right)$; they have special importance for describing adsorption process and achieving a reaction equilibrium. Whenever there is an adsorption equilibrium constant, then, the thermodynamic functions can be evaluated through equations 7 to $9 .^{32-33}$

$$
\begin{gathered}
K=\frac{C_{A S}}{C_{A}}=\frac{q_{e}}{C_{e}} \\
\Delta G_{\text {ads }}=-R T L n K
\end{gathered}
$$

Also, $\left(\Delta H_{a d s}\right)$ and $\left(\Delta S_{a d s}\right)$ can be calculated through equation 9 from the slope and interface of $\mathrm{LnK}$ against $1 / \mathrm{T}$ plot.

$$
\operatorname{LnK}=\frac{\Delta S_{a d s}}{R}-\frac{\Delta H_{a d s}}{R T}
$$

The equilibrium constant is calculated at any temperature using equation 7 .

The thermodynamic data graph of sulfate ion adsorption process by activated carbon is shown in Fig. 12 . Also, the extracted data from this graph is presented in Table 4 . According to the data presented in Table $4, \Delta H_{a d s}$,
$\Delta S_{a d s}$ and $\Delta G_{a d s}$ values are negative. Therefore, sulfate ion adsorption process by activated carbon is spontaneous. Given being negative, its adsorption percentage decreases with increasing temperature. Considering the enthalpy changes in anion's adsorption on the activated carbon surface, it can be said that the adsorption process is physical; because $\Delta \mathrm{H}<40 \mathrm{Kj} / \mathrm{mol}$. Since the adsorption process is exothermal, according to le Chatelier principle, it decreases with increasing temperature which is somehow accompanied by irregularities reduction. Moreover, Gibbs free energy for sulfate ions decreased by increasing temperature which indicated that when temperature increases, the amount of spontaneous adsorption process for anion decreases.

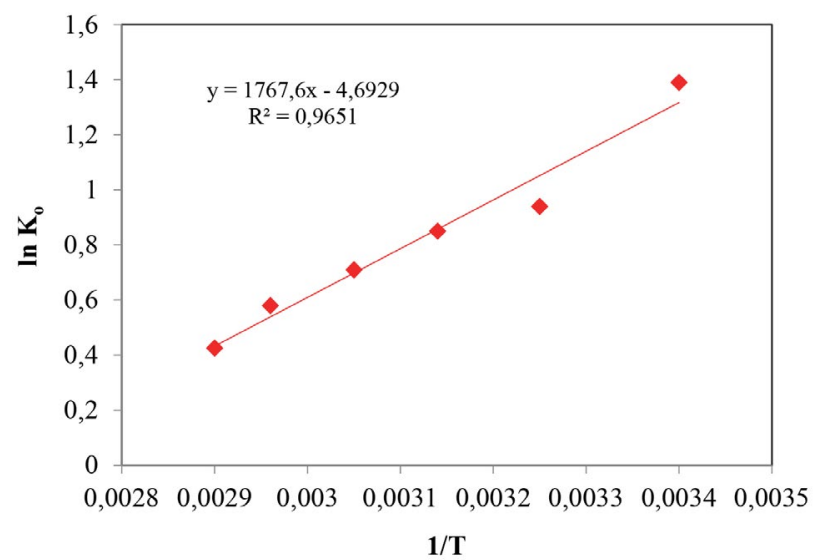

Figure 12. The $\ln \mathrm{K}_{\mathrm{o}}$ diagram versus $1 / \mathrm{T}$ for thermodynamic parameters estimation of sulfate ion adsorption from aqueous solution by activated carbon

\section{9. Kinetic Study of the Adsorption Process}

The adsorption kinetic study is highly important because it provides valuable information on the reaction

Table 4. Thermodynamic functions of $100 \mathrm{mg} / \mathrm{L} \mathrm{SO}_{4}^{2-}$ ion on the activated carbon surface derived from Lotus leaf (Other terms: $\mathrm{m}=0.5 \mathrm{~g}, \mathrm{pH}=6, \mathrm{Tc}=65 \mathrm{~min}$ )

\begin{tabular}{lcccc}
\hline $\mathbf{T}(\mathbf{K})$ & $\mathbf{K}$ & $\Delta \boldsymbol{G}_{\boldsymbol{a d s}}(\mathbf{k J} / \mathbf{m o l})$ & $\Delta \boldsymbol{H}_{\text {ads }}(\mathbf{k J} / \mathbf{m o l})$ & $\Delta \boldsymbol{S}_{a d s}(\mathbf{k J} / \mathbf{m o l})$ \\
\hline 298 & 4.15 & -3.44 & & \\
308 & 2.6 & -2.4 & & \\
318 & 2.33 & -2.31 & -15.12 & -40.09 \\
328 & 2.03 & -1.94 & & \\
338 & 1.87 & -1.63 & & \\
348 & 1.5 & -1.16 & & \\
\hline
\end{tabular}


pathway and the control mechanism of the adsorption process. ${ }^{23}$ In this study, first and second-order pseudo kinetic models were used for kinetic evaluation of sulfate ion on the activated carbon adsorbent. The linear form of the first and second-order kinetic models are presented in terms of equations 10 and 11 , respectively: ${ }^{35-37}$

$$
\begin{aligned}
& \log \left(q_{e / e x p}-q_{t}\right)=\log q_{e / c a l}-\frac{K_{1}}{2.303} t \\
& \frac{t}{q_{t}}=\frac{1}{K_{2} q_{e / c a l}^{2}}+\frac{t}{q_{e / c a l}}
\end{aligned}
$$

Here, $K_{1}$ pseudo-first-order reaction rate constant, $K_{2}$ pseudo-second-order reaction rate constant, $\mathrm{q}_{\mathrm{e} / \mathrm{cal}} \mathrm{com}$ putational equilibrium adsorption capacity $(\mathrm{mg} / \mathrm{g}), \mathrm{q}_{\mathrm{e} /}$ exp empirical equilibrium adsorption capacity $(\mathrm{mg} / \mathrm{g}), \mathrm{q}_{\mathrm{t}}$ adsorption capacity at the time $t(\mathrm{mg} / \mathrm{g})$ and $\mathrm{t}$ is the time (minute). In order to determine the reaction rate constant of $K_{1}$ and $\mathrm{q}_{\mathrm{e} / \mathrm{cal}}$, the $\log \left(\mathrm{q}_{\mathrm{e}, \exp }-\mathrm{qt}\right)$ graph was drawn based on $t$ and in order to determine the reaction rate constant of $K_{2}$ and $\mathrm{q}_{\mathrm{e} / \mathrm{cal}}$, in the second-order kinetic equation, the $\mathrm{t} /$ $\mathrm{q}_{\mathrm{t}}$ graph based on $\mathrm{t}$ was used.

The kinetic study results are shown in Table 5 and Fig. 13. By comparing the kinetic models' correlation coefficient $\left(\mathrm{R}^{2}\right)$, we can say that the kinetics of sulfate ion ad-
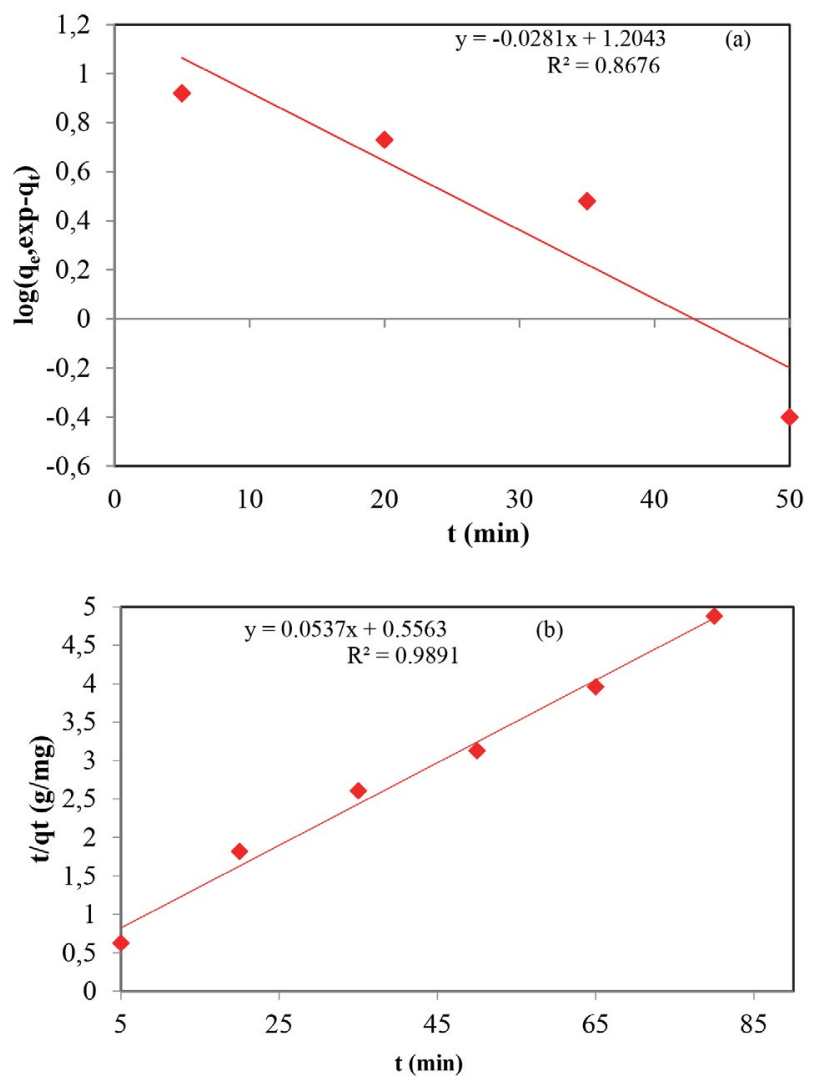

Figure 13. First-order kinetic (a) and second-order kinetic models (b) of $\mathrm{SO}_{4}^{2-}$ ion adsorption on the activated carbon surface derived from Lotus leaf sorption on the activated carbon derived from lotus leaves has the most conformity with the second-order pseudo model. Also, the $K_{1}$ value in the first-order pseudo mod$\mathrm{el}$ is less than $K_{2}$ second-order pseudo model. Therefore, sulfate ions adsorption through lotus leaves adsorbent follows the second-order kinetic model.

Table 5. Results of kinetic adsorption models of $100 \mathrm{mg} / \mathrm{L} \mathrm{SO} \mathrm{S}_{4}^{2-}$ ion on the activated carbon surface derived from Lotus leaf (Other terms: $\mathrm{T}=328 \mathrm{k}, \mathrm{m}=0.5 \mathrm{~g}, \mathrm{pH}=6, \mathrm{Tc}=65 \mathrm{~min}$ )

\begin{tabular}{lll}
\hline Kinetic models & Parameter & value \\
\hline Pseudo second-order & $q_{\mathrm{e} \text {,al }}(\mathrm{mg} / \mathrm{g})$ & 16 \\
& $K_{1}\left(\mathrm{~min}^{-1}\right)$ & 0.065 \\
& $\mathrm{R}^{2}$ & 0.8676 \\
Pseudo second-order & $q_{\mathrm{e} \text {, al }}(\mathrm{mg} / \mathrm{g})$ & 18.62 \\
& $K_{2}(\mathrm{~g} / \mathrm{mg} \mathrm{min})$ & 5.2 \\
& $\mathrm{R}^{2}$ & 0.9891 \\
\hline
\end{tabular}

\section{Conclusion}

In this study, sulfate ion adsorption from aqueous solutions through activated carbon adsorbent in the Lotus leaf was studied. Initially, activated carbon adsorbent was prepared and SEM, FTIR, BET, XRD, EDAX analyses were used to determine its surface properties. Then, the effect of various parameters such as $\mathrm{pH}$, temperature, contact time, initial sulfate ion concentration and adsorbent dose on the sulfate ion removal from aqueous solutions through adsorbent was investigated. The results showed that the highest sulfate ion removal efficiency occurs at $\mathrm{pH}=6, \mathrm{Tc}=65 \mathrm{~min}$, temperature $=25^{\circ} \mathrm{C}$, initial concentration of $20 \mathrm{mg} / \mathrm{L}$ and the adsorbent dose of 5 $\mathrm{g} / \mathrm{L}$. After determining the optimum terms, the isotherm, kinetics and thermodynamic behavior of the adsorption process was studied. Langmuir, Freundlich, Temkin and Dubinin-Radushkevich isotherm models were considered to study the adsorption process behavior. The results showed that the Langmuir isotherm model can better describe the equilibrium behavior of the adsorption process due to a higher correlation coefficient. Also, it was determined that sulfate ion adsorption process through lotus leaf adsorbent is physical. During the kinetic models examination, the first and second- order pseudo kinetics models were investigated. The kinetic analysis of the adsorption process was performed using laboratory data at different contact times. The results showed that the second-order pseudo kinetics model has a higher correlation coefficient. The thermodynamic adsorption behavior of sulfate ion through adsorbent was also studied. According to the results, Gibbs free energy for sulfate ions was obtained negative which represents that the adsorption process is possible and spontaneous. Also, the negative amount of enthalpy showed that the adsorption process 
was exothermal. Since the adsorption process is exothermal, according to le Chatelier principle, it decreases when temperature raises which is somehow accompanied by a decrease in irregularity. In addition, the amount of entropy was negative showing that the adsorption process is spontaneous.

\section{Conflict of Interests Statement}

The authors declare that there is no conflict of interests.

\section{References}

1. F. Ahmadi, H. Esmaeili. Desalin. Water Treat. 2018, 110, 154167. DOI:10.5004/dwt.2018.22228

2. R. Mahini, H. Esmaeili, R. Foroutan. Turk. J. Biochem. 2018 , 43, 623-631. DOI:10.1515/tjb-2017-0333

3. L. W. H. Pol, P. N. L. Lens, A. J. M. Stams, G. Lettinga. Biodegradation 1998, 9, 213-222.

DOI:10.1023/A:1008307929134

4. A. Teimouri, H. Esmaeili, R. Foroutan, B. Ramavandi. Korean J. Chem. Eng. 2018, 35, 479-488.

DOI:10.1007/s11814-017-0311-y

5. J. Y. park, Y. J. Yoo. Appl. Microbiol. Biotechnol. 2009, 82, 415429. DOI:10.1007/s00253-008-1799-1

6. H. Demiral, G. Gunduzogla. Bioresour. Technol. 2010, 101, 1675-1680. DOI:10.1016/j.biortech.2009.09.087

7. A. Goshadrou, A. Mohed. Desalination. 2010, 269, 170-176. DOI:10.1016/j.desal.2010.10.058

8. X. Wang, L. Chen, L. Wang, Q. Fan, D. Pan, J. Li, F. Chi, Y. Xie, S. Yu, C. Xiao, F. Luo, J. Wang, X. Wang, C. Chen, W. Wu, W. Shi, S. Wang, X. Wang. Sci. China Chem. 2019, 62, 933-967. DOI:10.1007/s11426-019-9492-4

9. X. Liu, R. Ma, X. Wang, Y. Ma, Y. Yang, L. Zhuang, S. Zhang, R. Jehan, J. Chen, X. Wang. Environ. Pollut. 2019.

DOI:10.1016/j.envpol.2019.05.050

10. S. M. Mousavi, S. A. Hashemi, A. M. Amani, H. Esmaeili, Y. Ghasemi, A. Babapoor, F. Mojoudi, O. Arjomand. Phys. Chem. Res. 2018, 6, 759-771.

11. Y. Wu, H. Pang, Y. Liu, X. Wang, S. Yu, D. Fu, J. Chen, X. Wang. Environ. pollution. 2019, 246, 608-620. DOI:10.1016/j.envpol.2018.12.076

12. Q. Huang, S. Song, Z. Chen, B. Hu, J. Chen, X. Wang. Biochar. 2019, 1, 45-73. DOI:10.1007/s42773-019-00006-5

13. M. J. Akhtar, S. Ullah, I. Ahmad, A. Rauf, S. M. Nadeem, M. Y. Khan, S. Hussain, L. Bulgariu. Chemosphere. 2018, 190, 234-242. DOI:10.1016/j.chemosphere.2017.09.136

14. G. Nacu, D. Bulgariu, M. Cristina Popescu, M. Harja, D. Toader Juravle, L. Bulgariu. Desalin. Water Treat. 2016, 57, 21904-21915. DOI:10.1080/19443994.2015.1128366

15. V. K. Gupta, I. Ali. J. Colloid Interface Sci. 2004, 271, 321-331. DOI:10.1016/j.jcis.2003.11.007

16. Z. Khademi, B. Ramavandi, M. T. Ghaneian. J. Environ. Chem. Eng. 2015, 3, 2057-2067. DOI:10.1016/j.jece.2015.07.012
17. S. M. Mousavi, S. A. Hashemi, H. Esmaeili, A. M. Amani, F. Mojoudi. Acta Chim. Slov. 2018, 65, 750-756.

DOI:10.17344/acsi.2018.4536

18. L. A. Rodrigues, M. L. C. P. da Silva, M. O. Alvarez-Mendes, Ad. R. Coutinho, G. P. Thim. Chem. Eng. J. 2011, 174, 49-57. DOI:10.1016/j.cej.2011.08.027

19. K. K. Singh, R. Rastogi, S. H. Hasan. J. Colloid Interface Sci. 2005, 290, 61-68. DOI:10.1016/j.jcis.2005.04.011

20. S. H. Min, J. S. Han, E. W. Shin, J. K. Park. Water Res. 2004, 38, 1289-1296. DOI:10.1016/j.watres.2003.11.016

21. M. Martınez, N. Miralles, S. Hidalgo, N. Fiol, I. Villaescusa, J. Poch. J. Hazard. Mater. 2006, 133, 203-211.

DOI:10.1016/j.jhazmat.2005.10.030

22. V. K. Gupta, C. K. Jain, I. Ali, M. Sharma, V. K. Saini. Water Res. 2003, 37, 4038-4047.

DOI:10.1016/S0043-1354(03)00292-6

23. J. Anwar, U. Shafique, M. Salman, A. Dar, S. Anwar. Bioresour. Technol. 2010, 101, 1752-1762.

DOI:10.1016/j.biortech.2009.10.021

24. E. I. El-Shafey. J. Hazard. Mater. 2007, 147, 546-556 DOI:10.1016/j.jhazmat.2007.01.051

25. A. O. Zer, C. Pirinc. J. Hazard. Mater. 2006, 137, 849-858 DOI:10.1016/j.jhazmat.2006.03.009

26. R. A. K. Rao, M. A. Khan, F. Rehman. Chem. Eng. J. 2010, 156, 106-113. DOI:10.1016/j.cej.2009.10.005

27. M. Harja, G. Buema, L. Bulgariu, D. Bulgariu, D. M. Sutiman, G. Ciobanu. Korean J. Chem. Eng. 2015, 32, 1804-1811. DOI:10.1007/s11814-015-0016-Z

28. M. Shams, I. Nabipour, S. Dobaradaran, B. Ramavandi, M. Qasemi, M. Afsharnia. Fresen. Environ. Bull. 2013, 22, 723727.

29. S. Tamjidi, H. Esmaeili, Chem. Eng. Technol. 2019, 42, 607616. DOI:10.1002/ceat.201800488

30. L. S. Panchakarla, A. Govindaraj, C. N. R. Rao. Inorg. Chim. Acta. 2010, 363, 4163-4174. DOI:10.1016/j.ica.2010.07.057

31. V. J. Larson, H. H. Schierup. J. Environ. Qual. 1981, 10, 188193. DOI:10.2134/jeq1981.00472425001000020013x

32. I. Volf, N. G. Rakoto, L. Bulgariu. Sep. Sci. Technol. 2015, 50, 1577-1586. DOI:10.1080/01496395.2014.978018

33. D. Bulgariu, L. Bulgariu. Bioresour. Technol. 2012, 103, 489493. DOI:10.1016/j.biortech.2011.10.016

34. H. Esmaeili, R. Foroutan. J. Dispers. Sci. Technol. 2018. DOI:10.1080/01932691.2018.1489828

35. L. Bulgariu, D. Bulgariu, M. Macoveanu. Sep. Sci. Technol. 2011, 46, 1023-1033. DOI:10.1080/01496395.2010.536192

36. R. Foroutan, H. Esmaeili, S. M. D. Rishehri, F. Sadeghzadeh, S. R. Mirahmadi, M. Kosarifard, B. Ramavandi. Data Brief. 2017, 12, 485-492. DOI:10.1016/j.dib.2017.04.031

37. G. Nacu, L. N. Nemes, L. Bulgariu. Rev. Roum. Chim. 2017, $62,439-447$. 


\section{Povzetek}

V članku so preučevali potencial aktivnega oglja pridobljenega iz listov lotusa Ziziphus spina-christi za odstranjevanje sulfatnih ionov iz vodnih raztopin. S tem namenom so preučili vpliv različnih parametrov kot so $\mathrm{pH}$ vrednost, kontaktni čas, temperatura, koncentracija adsorbenta in začetna koncentracija sulfatnih ionov. Rezultati so pokazali, da je bila največja adsorpcijska učinkovitost ( $84.5 \%$ ) dosežena pri pH vrednosti 6 , koncentraciji adsorbenta $5 \mathrm{~g} / \mathrm{L}$, koncentraciji sulfatnih ionov $20 \mathrm{ppm}$, času $65 \mathrm{~min}$ in temperaturi $45^{\circ} \mathrm{C}$. Študija adsorpcijskega ravnotežja je pokazala, da lahko proces opišemo z Langmuirjevo adsorpcijsko izotermo z maksimalno kapaciteto vezave $9.3 \mathrm{mg} / \mathrm{g}$. Termodinamska študija je pokazala, da je proces adsorpcije na površino aktivnega oglja spontan in eksotermen, kinetiko adsorpcije pa lahko opišemo $\mathrm{z}$ modelom psevdo-drugega reda. 